\title{
ANALISIS GEJALA KLINIS DAN PENINGKATAN KEKEBALAN TUBUH UNTUK MENCEGAH PENYAKIT COVID-19
}

\section{Analysis of Clinical Symptoms and Immune Enhancement to Prevent COVID-19 Disease}

\author{
Lia Amalia, ${ }^{1}$ Irwan $^{2}$ Febriani Hiola ${ }^{3}$ \\ 1,2,3 Jurusan Kesehatan Masyarakat, FOK UNG, Gorontalo \\ e-mail: fbrnhiola@gmail.com
}

\begin{abstract}
Abstrak
Pandemi Covid-19 menggemparkan dunia. Virus baru ini telah menginfeksi lebih dari 850 ribu orang di berbagai belahan dunia. WHO dan Centers for Disease Control and Prevention (CDC) telah banyak memberikan informasi terkait bagaimana ciri ciri infeksi virus corona baru bagi seseorang.

Karena Virus corona adalah jenis virus baru yang memiliki gejala-gejala yang bisa dikategorikan apakah seseorang terpapar atau tidak. Berdasarkan data kesehatan oleh lembaga Immune Deficiency Foundation virus corona menular dari kontak perorangan dan menyerang system pernapasan. Juga akan mudah menginfeksi seseorang yang memiliki system imun yang rendah. Bagaimana cara agar imun kita tidak rendah pada masa pandemi covid-19 ini?. Makalah ini dibuat dengan tujuan untuk mengetahui gejala klinis dan cara meningkatkan sistem kekebalan tubuh untuk mencegah penyakit Covid-19. Metode pengambilan data dilakukan dengan membaca dan menganalisis dari berbagai sumber.

Kata kunci: Covid-19, Imunitas, Pandemi
\end{abstract}

\begin{abstract}
Abstrak
The Covid-19 pandemic shocked the world. This new virus has infected more than 850 thousand people in various parts of the world. WHO and the Centers for Disease Control and Prevention (CDC) have provided a lot of information regarding how to characterize a new corona virus infection for a person. Because this virus is a new strain, over time, symptoms to identify a person whether he is exposed to the corona virus or not continue to be reported.

According to health data published by the Immune Deficiency Foundation, the Corona virus is a virus that attacks the respiratory system and is easily transmitted through personal contact. In addition, people with low immunity are also at high risk of corona virus infection. How do you keep your immunias not low during this co-19 pandemic? This paper was made with the aim of knowing clinical symptoms and ways to improve the immune system to prevent Covid-19 disease. Data collection method is done by reading and analyzing from various sources.
\end{abstract}

Keywords: Covid-19, Immunity, Pandemic 


\section{PENDAHULUAN}

Corona atau COVID-19, kasusnya dimulai dengan pneumonia atau radang paruparu misterius pada Desember 2019. Kemungkinan hal ini berkaitan dengan adanya pasar hewan Huanan di kota Wuhan yang melakukan transaksi jual beli berbagai jenis daging binatang, salah satunya daging yang tidak bisa dikonsumsi seperti ular, kelelawar dan berbagai jenis tikus. Kasus ini paling banyak ditemukan di pasar hewan Huanan di kota Wuhan. Virus ini di duga berasal dari kelelawar dan hewan lain yang dikonsumsi manusia sehingga menular kepada orang lain.

Virus corona pada dasarnya sudah tidak asing di dunia kesehatan hewan, ada beberapa jenis yang mampu menginfeksi manusia sehingga menjadi penyakit radang paru. Jauh sebelum pandemic covid-19, dunia sempat heboh dengan penyakit Sars dan Mars yang punya kaitan dengan virus corona. Sehingga dari kasus diatas menandakan virus corona bukan hal yang pertama kali terjadi. Gejala yang di timbulkan hamper sama dengan flu tetapi virus corona lebih cepat berkembang sehingga akibatnya menimbulkan infeksi yang lebih parah dan berdampak pada gagal organ.

Sejak awal munculnya kasus virus corona, imbauan untuk rajin mencuci tangan dan menjaga imunitas tubuh. Hal ini dianggap remeh oleh sebagian msyarakat . Tetapi hal ini bukanlah tanpa alasan. Salah satu tim pakar gugus tugas penangan Coid-19, Wiku Adisasmito mengatakan bahwa pasien covid-19 dapat sembuh dengan imunitas tubuh. Penyakit korona bisa disembuhkan dengn sendirinya atau self limiting disease. Hal yang sama juga diungkapan oleh Menteri Kesehatan Terawan Agus Putranto. Hal ini juga berlaku untuk virus covid-19. Memiliki sistem imun yang kuat adalah cara untuk melawan virus.

Ketika virus corona masuk kedalam tubuh manusia dan menulr dari binatang atau, manusia sehingga musuh akan teridentifikasi oleh tubuh. Usaha tubuh dalam melawan virus ini dengan terdapatnya gejala-gejala pada pasien yang terinfeksi. Wiku menjelaskan tubuh mkhluk hidup akan menjadi tempat untuk virus mencari peluang hidup Ketika terjadi penularan maka tubuh yang rentan akan mudah terinfeksi. Oleh karena itu, sangat penting dalam menjaga sistem imunitas tubuh. Akibat dari risiko adanya peningkatan kasus corona dengan menurunnya imunitas tubuh serta riwayat penyakit lain yang dapat melemahkan tubuh.

Salah satunya mencegah penyakit yang disebabkan virus corona adalah dengan cara meningkatkan sistem imun atau daya tahan tubuh. Cara yang bisa dilakukan untuk meningkatkan imunitas tubuh dengan melakukan pola hidup sehat seperti lebih banyak mengkonsumsi sayur dan buah, karena seseorang tidak mudah sakit jika lebih banyak mengonsumsi 2 jenis makanan tersebut. Cukup waktu istirahat bisa memelihara daya tahan tubuh, karena apabila kurang waktu istirahat dapat menurunkan sistem imunitas tubuh seseorang. Kekebalan tubuh bersifat dinamis, dapat naik turun. Usia, nutrisi, vitamin, mineral, hormon, olahraga dan emosi mempengaruhi imunitas tubuh. Kuatnya anti bodi menandakan seseorang tersebut semakin dewasa. Tetapi, dengan bertambahnya usia bisa juga antibodi melemah. Melakukan pola hidup sehat dapat menjaga dan memperbaiki sistem imun tubuh. Hal ini berarti sehat dengan mengkonsumsi makanan bernutrisi dan berolahraga. Menurut Prof iris mengatakan bahwa sistem imun dapat di tingkatkan dengan mengatur sistem imunitas tubuh dengan menggunakan imunostimulan. Didalam sistem imun, terdapat Imunostimulan yang bekerja dalam mengaktifkan berbagai elemen dan mekanisme berbeda.

Fungsi imunostimulan dapat meningkatkan pertahanan alamiah tubuh dalam mengatasi berbagai infeksi virus dan bakteri 
serta penyakit lainnya yang dapat menurunkan atau menekan sistem imun. Selain itu, imunostimulan berfungsi dalam membantu sistem kerja imun dengan cara merangsang pembentukkan berbagai sel-sel imun yang mempunyai peran penting, dengan meningkatkan pembentukkkan ntibodi dan sitokin serta memperbaiki fungsi fagosistosi. Prof Iris mengtakan bahwa orang-orang yang merencanakan berpergian dan berada di tempat-tempat keramaian wajib menggunakan imunostimulan. Juga hal ini berlaku untuk kelompok usia lanjut yang memiliki imunitas rendah ( $>60$ tahun).

Menurut Prof Iris dalam kondisi saat ini menjaga dan meningkatkan daya tahan tubuh menjadi sangat penting dan diperhatikan oleh semua orang.

\section{METODE PENELITIAN}

Dengan menelaah sumber pustaka dan dokumen terkait baik berupa jurnal, bukubuku atau laporan penelitian lainnya. Hasil dari berbagai telaah sumber pustaka dan dokumen digunakan untuk menganalisis gejala klinis dan peningkatan imunitas tubuh untuk mencegah penyakit virus corona kemudian dijadikan satu untuk menjadi sebuah bacaan

\section{HASIL DAN PEMBAHASAN \\ 3.1 Definisi Virus Corona}

Definisi Virus Korona adalah keluarga besar virus yang menyebabkan penyakit Middle East Respiratory Syndrome (MERS), Severe Acute Respiratory Syndrome (SARS) dan Virus Korona yang paling baru ditemukan COVID-19 (Coronavirus disease 2019). Pada tahun 2002 SARS pertama kali mewabah di Tiongkok, dan pada tahun 2012 pertama kali muncul di Timur Tengah. Adanya penyakit baru di Tiongkok yang dinamakkan covid19 ini menyebabkan banyak kematian di berbagai Negara (pandemi) yang terjadi pada akhir tahun 2019.
Masa inkubasi adalah rentang waktu antara terjadinya infeksi, dan Lama gejala yang ditimbulkan oleh virus ini yaitu 1-14 hari. Penularan jenis virus ini jika penderita covid-19 bersin atau batuk, selanjutnya seseorang menghirup percikan air liur tersebut. Cepatnya penularan covid-19 jika di bandingkan dengan SARS dan MERS angka kematian dengan SARS (10\%) dan MERS (37\%) lebih tinggi dari angka kematian akibat covid-19. Akibat begitu cepatnya penularannya, terjadi peningkatan tajam kasus covid-19 dalam waktu singkat. Jika dibandingkn dengan kasus SARS dan MERS.

Sebagian besar orang (sekitar 80\%) jika memiliki imunitas tubuh yang kuat akan pulih dari penyakit tanpa perlu perawatan khusus karena sifat virus bersifat self medication.

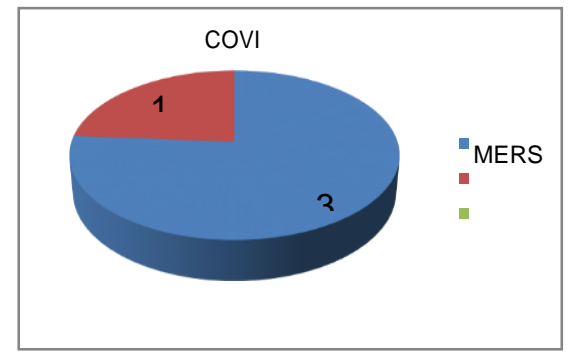

\subsection{Pengertian Imunitas}

Imunitas adalah cara tubuh mnusia dalam melawan dan membunuh benda asing seperti bakteri, virus dan organ transplantasi lainnya apabila di transplantasikan ke dalam tubuh maka tubuh menganggap benda asing tersebut bukan dari dri jaringan tubuh sehingga tubuh akan menolaknya. Virus corona juga seperti virus pada umumnya yang hanya menyerang jika imunitas tubuh lemah.

\subsubsection{Konsumsi bahan makanan peningkat kekebalan tubuh}

Agar imun kita kuat maka perlu senantiasa dijaga dengan memperhatikan jenis makanan yang dapat meningkatkan daya tahan tubuh, mengonsumsi vitamin dan suplemen, misalnya vitamin $\mathrm{C}$ yang terdapat pada buah 
jeruk, strowberi,sayur bayam, paprika merah dan brokoli. Vitamin A mengndung antioksidan untuk menangkal radikal bebas dan meningkatkan kekebalan tubuh, yang ada pada wortel, labu kuning dn ubi.

\subsubsection{Berolahraga dengan Rutin}

Untuk meningkatkan daya tahan tubuh dan meredakan peradangan dengan melakukan olahraga secara rutin. Melakukan olahraga secara teratur, efeknya lebih baik terhadap sistem imun jika dibandingkan dengan olahraga yang hanya dilakukan sekli saja. Olahraga bisa merangsang kinerja antibodi dan sel-sel darah putih bisa bersirkulasi lebih cepat. Sel darah putih merupakan sel kekebalan tubuh yang melawan berbagai penyakit.

\subsubsection{Jangan Dehidrasi}

Lebih dari $60 \%$ tubuh terdiri dari air. Menurut WHO, kebutuhan air minum orang dewasa rata-rata sekitar 8 gelas atau 2 liter. Jika melakukan aktivitas berlebih seperti olah raga atau ketika cuaca panas maka diharuskan untuk memperbanyak minum air. Kekurangan minum menyebabkan dehidrasi. Saat dehidrasi, tubuh lebih cepat lelah, daya tahan melemah, dan paparan virus bisa mudah menginfeksi.

\subsubsection{Rajin cuci tangan.}

Telapak tangan adalah salah satu bagian dari tubuh yang paling rentan menjadi sarang bagi virus. Oleh karena itu, tidak boleh terlalu sering menyentuh bagian mata, hidung dan mulut. karena hal tersebut dapat menjadi penyebab penularan virus yang masuk ke dalam tubuh dan membuat sakit melalui tangan ke mata hidung atau mulut. Selain itu ada juga cara lain untuk dapat melindungi diri dari virus korona dengan melakukan cuci tangan secara rutin. Dengan menjadikan cuci tangan sebagai kebiasaan maka hal ini dapat membantu mematikan kuman yang ada di tangan. Menggunkan air bersih dan sabun atau cairan berbasis alcohol untuk mencuci tangan secara teratur dan menyeluruh.

\subsubsection{Hindari stress}

Jangan sampai pemberitaan virus corona maupun konten-konten di media sosial menyebabkan stress terus menerus. Fungsi kekebalan tubuh akan menurun jika terjadi peningkatan hormone kortisol yang menjadi penyebab stres. Orgnisasi kesehatan dunia (WHO) menyarankan untuk membatasi dalam mencari informasi terkait kasus covid-19 yang saat ini lebih banyak konten hoax dibandingkan informas yang kredibel terkait virus korona. Melakukn karantina di dalam rumah merupakan salah satu cara pemerintah untuk memutuskn mata rantai penularan virus ini. kebijakan baru ini dilakukan pemerintah di masing-masing Negara karena covid-19 sudah menjadi pandemic di beberapa negara.

Tabel 1. Factor penurun dan peningkat imunitas

\begin{tabular}{|c|c|c|c|}
\hline No & $\begin{array}{c}\text { Faktor Penurun } \\
\text { Imunitas }\end{array}$ & $\mathrm{NO}$ & $\begin{array}{c}\text { Faktor Peningkat } \\
\text { Imunitas }\end{array}$ \\
\hline 1 & Stres & 1 & Hindari Stres \\
\hline 2 & Kurang Gerak & 2 & $\begin{array}{l}\text { Rutin } \\
\text { Berolahraga } \\
\end{array}$ \\
\hline 3 & Kurang Tidur & 3 & $\begin{array}{l}\text { Hindari Rokok } \\
\text { dan Alkohol }\end{array}$ \\
\hline 4 & Dehidrasi & 4 & $\begin{array}{l}\text { Konsumsi } \\
\text { Suplemen } \\
\end{array}$ \\
\hline 5 & $\begin{array}{l}\text { Kurangnya } \\
\text { asupan nutrisi } \\
\text { yang diperlukan }\end{array}$ & 5 & $\begin{array}{l}\text { Mengonsumsi } \\
\text { buah dan sayur }\end{array}$ \\
\hline
\end{tabular}

\section{KESIMPULAN}

Dalam kondisi pandemik virus corona sekarang ini, selain menjaga pola hidup sehat perlu juga menjaga daya tahan tubuh imun. imun merupakan sistem pertahanan dari berbagi struktur biologis dan proses yang melindungi tubuh dari penyakit. Oleh karena itu sangat penting dalam menjaga imunits tubuh. Terjadi peningkatan risiko corona jika sejalan dengan imunits tubuh manusia yang menurun dan juga adanya penyakit lain yang bisa memicu lemahnya tubuh. Cara yang bisa digunakan adalah melakukan pola hidup sehat, tidak stress, rajin berolahraga dan hal-hal lainnya agar daya tahan tubuh kamu semakin 
kuat menahan paparan virus corona.

\section{UCAPAN TERIMA KASIH}

Saya sebagai penyusun mengucapkan banyak terimakasih kepada semua pihak yang telah membantu saya dalam menyusun makalah ilmiah ini. Sehingga makalah ilmiah ini dapat selesai dan semoga bisa menjadi bacaan yang bermanfaat bagi semuanya.

\section{DAFTAR PUSTAKA}

[1] Widiyani R. Latar Belakang Virus Corona, Perkembangan hingga Isu Terkini. Rabu, 18 maret 2020. [diakses tanggal $10 \quad$ Mei 2020].Availableathttps://news.detik.com/b erita/d-4943950/latar-belakang-viruscorona-perkembangan-hingga-isu-terkini

[2] CNN Indonesia. alasan di Balik Imunitas Tubuh Kuat Bisa Cegah Covid-19. Rabu, 18 maret 2020. [diakses tanggal 10 Mei 2020].Availableathttps://www.cnnindon esi a.com/gaya-hidup/20200318125414255-484489/alasan-di- balik-imunitastubuh-kuat-bisa-cegah-covid-19

[3] Haidi F. Tangkal Penyakit Bisa dengan Cara Meningkatkan Sistem Kekebalan Tubuh. 28 Januari 2020. [diakses tanggal 10 Mei 2020]. Available at: https://www.borneonews.co.id/berita/15 4600-tangkal-penyakit-bisa-dengancara- meningkatkan-sistem-kekebalan$\underline{\text { tubuh }}$

[4] Handayani I. Antibodi, Perlindungan Terbaik Hadapi Ancaman Virus Korona. 23 Februari 2020. [diakses tanggal 11 Mei
2020].Availableat:https://investoridlifest yle /antibodi-perlindungan-terbaik$\underline{\text { hadapi-ancaman-virus-korona }}$

[5] Arif A. Wajib Baca, Tips Tingkatkan Sistem Imun untuk Tangkis Covid-19.2 April 2020. [diakses pada tanggal 10 mei 2020].Availableat:https://m.ayosemarang. com/read/2020/04/02/54679/wajib-bacatips-ti ngkatkan-sistem-imun-untuktangkis-covid- 19

[6] Reza. Siap Hadapi Virus Corona dengan Tingkatkan Imunitas Tubuh. 21 Mar 2020. . [diakses pada tanggal 10 mei 2020]. Available at:https://m.liputan6.com/health/read/420 7368/siap-hadapi-virus-corona-dengantingkatkan-imunitas-tubuh

[7] Abdi H. 5 Penyebab Sistem Imun Lemah dan Cara Mengatasinya. 22 Februari2020. [diakses pada tanggal 10 mei 2020]. Available at:https://hot.liputan6.com/rea d /4185028/5-penyebab-sistem-imunlemah-dan-cara- mengatasinya\#

[8] Liputan6.com. "cegah virus corona dengan perkuat sistem imun tubuh". Tanggal 20 Februari 2020. [diakses pada tanggal 10 mei 2020].Available at:https://m.liputan6.

com/health/read/4183757/cegah-virus-coro na-dengan-perkuat-sistem-imun-tubuh

[9] Mutiara Patricia Ladimo, Irwan Irwan MERS-CoV (Middle East Respiratory Syndrome-Corona Virus) menggegerkan dunia timur. Journal health and sciens : Gorontalo Journal Health \& Sciens Community, Vol. 4 No.1 2020 http://ejurnal.ung.ac.id/index.php/gojhes /article/view/4666 
Vol. 2, No 2 (2020) : Juli

.DOI : 10.3 5971/gojhes.v4i1.4666

\{10\}Sunarto Kadir , 2019 ; Faktor Penyebab Anemia Defisiensi Besi Pada Ibu Hamil Di Wilayah Kerja Puskesmas Bongo Nol Kabupaten Boalemo. Jambura Journal Of Health Science And Research Volume 1 No.2 Tahun 2019. http://ejurnal.ung.ac.id/index.php/jjhsr/issu e/view/207

Doi :

Https://Doi.Org/10.35971/Jjhsr.V1i2.2396

\{11).Irwan \{2018\} Model of Hypertension Transmission Risks to Communities in Gorontalo Province. ISSN : 0976-0245 \{print 0976-5506(Electronic Indian Journalof Public Health Research \& Development Volume 9 Nomor 1 Januari 2018.

http://www.indianjournals.com/IJOR.AS PX?target $=$ ijor:ijphrd $\&$ volume $=9 \&$ issue $=$ $\underline{1 \& \text { article }=058}$ 